\title{
Molecular analysis of a gene encoding a serum-resistance-associated 76 kDa surface antigen of Haemophilus somnus
}

\author{
S. P. Cole, ${ }^{1,2 *}$ D. G. GuineY ${ }^{2}$ and L. B. CorbeiL ${ }^{1}$ \\ Departments of Pathology and Medicine ${ }^{2}, 8416$, University of California San Diego Medical Center, \\ 200 W. Arbor Dr., San Diego, California 92103-8416, USA
}

(Received 9 February 1993; revised 17 May 1993; accepted 25 May 1993)

\begin{abstract}
Haemophilus somnus is a Gram-negative bacterial bovine pathogen which can cause disease or be carried asymptomatically. We previously showed that four serum-sensitive isolates from asymptomatic carriers lacked a 13.4 kb sequence of chromosomal DNA that was present in two virulent serum-resistant strains. We have since sequenced $5 \mathrm{~kb}$ of the $13.4 \mathrm{~kb}$ fragment from a serum-resistant strain, which contained an open reading frame (ORF) of at least $4.5 \mathrm{~kb}$. From Western blot analysis, the ORF was shown to encode a $76 \mathrm{kDa}$ protein (p76) that co-migrated with a $76 \mathrm{kDa} H$. somnus surface protein. Both the recombinant and natural p76 reacted with convalescent-phase serum from a cow in an experimental $H$. somnus abortion study. The translational start site for 776 was identified by deletion analysis of subclones of the $5 \mathrm{~kb}$ cloned sequence. The $4.5 \mathrm{~kb}$ ORF contained $1.2 \mathrm{~kb}$ tandem direct repeats (DRs), with $65 \%$ identity between the two repeats at the protein level. The $5^{\prime}$ DR (DR1) included the start site for the $76 \mathrm{kDa}$ protein, and DR2 had a flanking inverted repeat, suggestive of an insertion-sequence-like element.
\end{abstract}

\section{Introduction}

The bovine pathogen Haemophilus somnus is the causative agent of a wide range of both septicaemic and nonsepticaemic syndromes including pneumonia, infertility and the sequelae of septicaemia: abortion, meningoencephalitis, arthritis and myocarditis (for reviews, see Harris \& Janzen, 1989; Humphrey \& Stephens, 1983; Kwiecien \& Little, 1991). The infection may be sexually transmitted also (Kwiecien \& Little, 1991), since a genital asymptomatic carrier state is common. Most normal bulls are preputial carriers and some normal cows are vaginal carriers (Kwiecien \& Little, 1991). Others have shown that genital isolates from asymptomatic carriers are avirulent or less virulent than isolates from diseased animals (Groom et al., 1988; Humphrey, 1982; Humphrey \& Stephens, 1983; Inzana \& Todd, 1992). Our own studies (Corbeil et al., 1985) demonstrated that several preputial isolates from asymptomatic carriers were serum-sensitive, whereas all isolates

*Author for correspondence. Tel. (619) 5436146 ; fax (619) 543 6614.

Abbreviation: DR, direct repeat.

The GenBank accession number for the sequence of the entire $4.5 \mathrm{~kb}$ ORF reported in this paper is $\mathrm{L} 10282$. that could be causally associated with disease were serum-resistant. The resistance to killing by fresh bovine serum was associated with the presence of 270 and $41 \mathrm{kDa}$ outer-membrane proteins (OMPs) (Widders et al., 1989) and/or lipooligosaccharide with multiple bands on silver-stained gels (Inzana \& Todd, 1992). The 270 and $41 \mathrm{kDa}$ OMPs (p270 and p41) were both immunoglobulin-binding proteins (IgBPs; Yarnall et al., $1988 a, b)$.

A cosmid library from a virulent, serum-resistant strain produced a clone that expressed two additional but related serum-resistance-associated proteins at 76 and $120 \mathrm{kDa}(\mathrm{p} 76$ and $\mathrm{p} 120)$ that reacted with antiserum to the $270 \mathrm{kDa}$ IgBP (Corbeil et al., 1988; Cole et al., 1992). The proteins were visualized by Western blot, reacting with protective convalescent serum or antiserum to the $270 \mathrm{kDa}$ IgBP. Later, the genes for these two proteins were localized to a $13.4 \mathrm{~kb}$ sequence (Cole et al., 1992). Southern blots showed that two virulent, serumresistant isolates contained this sequence, whereas four serum-sensitive strains from asymptomatic carriers lacked this segment of DNA (Cole et al., 1992). Additional Southern blots with probes constructed from fragments of each of these two genes showed no crosshybridization, suggesting that $\mathrm{p} 76$ and $\mathrm{p} 120$ had no significant DNA homology. Because both proteins reacted with polyclonal antibody to p270, the lack of

0001-8152 C 1993 SGM 
homology between the two indicated that $\mathrm{p} 270$ may be a polymer of $\mathrm{p} 76$ and $\mathrm{p} 120$.

In this paper, we present the sequence of the gene for the $76 \mathrm{kDa}$ protein. By analysis of Western blots of proteins expressed by subclones, we determined the probable start codon of the $\mathrm{p} 76$ gene. We also report the existence of a large insertion-sequence-like direct repeat within this gene and upstream regions of $H$. sommus chromosomal DNA.

\section{Methods}

Bacterial strains and plasmids. $H$. somnus isolates were grown in brain heart infusion medium (Difco) supplemented with $0.1 \%$ Trizma base and $0-001 \%$ thiamin monophosphate (BHITT), as described previously (Inzana \& Corbeil, 1987). Solid medium was BHITT agar plus $5-10 \%$ (v/v) calf blood, as described (Cole et al., 1992). Serumresistant strain 2336 , from which all the subclones were derived, was isolated from a pneumonic calf and has been used to reproduce $H$. somnus pneumonia (Gogolewski et al., 1987). The subclones in this paper were derived from cosmid pHSl (Corbeil et al., 1988), containing a $35 \mathrm{~kb}$ insert of $H$. somnus DNA in $E$. coli DHI. Transformants in $E$. coli DH5 $\alpha$ were grown in LB medium (Sambrook et al., 1989) supplemented with ampicillin at $100 \mu \mathrm{g} \mathrm{ml}^{-1}$.

Recombinant DNA techniques and subclone construction. DNA isolation for construction of plasmids and subclone analysis was by the boiling method (Holmes \& Quigley, 1981). All other DNA manipulations were carried out using standard protocols (Sambrook et al., 1989). Plasmids pHS139 and a derivative, pHS138, were constructed as previously described (Cole et al., 1992). Briefly, pHS139 consisted of a $5 \mathrm{~kb} X b a \mathrm{I}-P v u \mathrm{II}$ insert from $\mathrm{pHS} 1 \mathrm{in} \mathrm{pUC19}$, while the derivative pHS138 contained a $3 \mathrm{~kb}$ Hpal-PvuII insert cloned in pUC18. Deletion derivatives of pHS138 were made using appropriate restriction enzymes, followed by religation of the plasmid. Specifically, pHS176 was constructed by cloning the PvuI- $P_{s t} \mathrm{I}$ fragment from pHS138 into the Smal-PstI site of pUC18. This resulted in the p76 gene lying just downstream of the $\mathrm{pUCl} 8$ lacZ start site. Plasmid $\mathrm{pHS} 182$ was made by treating pHS176 with EcoRI, filling in the ends with the large fragment (Klenow) of DNA polymerase, then religating the plasmid. This treatment placed the $p 76$ gene out of frame with respect to the lac $Z$ ATG start site. Finally, plasmid pHSI71 was prepared by digestion of pHS138 with $B s t \mathrm{BI}$ and $E c o$ RI, followed by religation. All of these plasmids were tested by restriction analysis and gave the appropriate sized fragments.

SDS-PAGE and Western blots. Western blots were from $8 \%$ SDSpolyacrylamide gels of whole cell lysates. The cells were prepared for loading in sample buffer as previously described (Cole et al., 1992). Briefly, cultures were adjusted to an optical density of 0.4 at $600 \mathrm{~nm}$, and then a $1.5 \mathrm{ml}$ vol. was pelleted and resuspended in $100 \mu \mathrm{l}$ of sample buffer prior to loading $3 \mu \mathrm{l}$ in the wells. After electrophoresis, proteins were electrotransferred to nitrocellulose (Schleicher and Schuell) as previously described (Cole $e t$ al., 1992). Filter blots were made from the gel, and reacted with a $1: 2000$ dilution of serum P3, as before (Corbeil et al., 1988; Cole et al., 1992). Serum P3 was convalescent phase serum taken from a cow in an experimental abortion study using a serumresistant strain of $H$. somnus (Widders et al., 1986). This serum reacts with the $270 \mathrm{kDa}, 120$ and $76 \mathrm{kDa}$ antigens as well as other $H$. somnus antigens not expressed in the $E$. coli recombinants reported in this study (Corbeil et al., 1988; Cole et al., 1992). Specific antiserum to $\mathrm{p} 270$ was raised in rabbits by inoculation of the gel-purified antigen as previously described (Yarnall et al., 1988b). The antiserum reacts only with $H$. somnus antigens $\mathrm{p} 270, \mathrm{p} 120$ and $\mathrm{p} 76$, even though there is no significant DNA homology between $\mathrm{p} 76$ and p120 (Cole et al., 1992). This suggested that $\mathrm{p} 76$ and p120 may be subunits of p270 (Cole et al., 1992). Gamma-Bind G-horse radish peroxidase conjugate (Genex Corp.) at a 1:2000 dilution was used to detect antigen-antibody reactions, with the addition of 4-chloro-1-naphthol and hydrogen peroxide.

Sequencing strategy. Double-stranded sequencing was carried out using dideoxynucleotide termination reactions with T7 DNA polymerase in a multiwell microtitre plate system (Amersham). To resolve some ambiguous sequences, Taq polymerase (Promega) was used at higher temperatures. Clones and subclones were sequenced using both forward and reverse universal pUC primers and overlapping areas with synthetic primers (from Molecular Biology Core Facility, University of California, San Diego, CA).

Data analysis. DNA was analysed using DNA Strider (shareware) and MacVector software (International Biotechnologies Inc.).

\section{Results and Discussion}

Cosmid pHS1 contained a $35 \mathrm{~kb}$ insert from $H$. somnus that expressed a $76 \mathrm{kDa}$ antigen and low levels of a group of $H$. somnus antigens centred at $120 \mathrm{kDa}$ on SDSPAGE gels when expressed in E. coli (Corbeil et al., 1988). A $12 \mathrm{~kb}$ section of the cosmid insert was subcloned into the vector pUCl9 (creating pHS134). This plasmid expressed high levels of the $120 \mathrm{kDa}$ group of proteins, as well as the $\mathrm{p} 76$ and lower molecular mass proteins (Cole et al., 1992). Further subcloning of this insert into pHS139 and pHS140 on pUC-based vectors resulted in the expression of $120 \mathrm{kDa}$ proteins from $\mathrm{pHS} 140$, while pHS139 produced large amounts of p76, as well as lower molecular mass proteins (Cole et al., 1992). Expression was determined by Western blots using cell lysates of the subclones reacted with convalescent phase serum or polyclonal antiserum to $\mathrm{p} 270$, which reacts with both $\mathrm{p} 76$ and p120 (Cole et al., 1992). The $5 \mathrm{~kb} \mathrm{XbaI-PvuII} \mathrm{insert}$ in plasmid pHS139 was subcloned in pUC-based vectors in either orientation with respect to the $l a c Z$ promoter to give pHS138 and $\mathrm{pHS} 137$. Both of these plasmids contained $3 \mathrm{~kb} \mathrm{HpaI-PvuII}$ inserts. For pHS138, expression from the lac $Z$ promoter resulted in large quantities of a $76 \mathrm{kDa}$ protein, as well as several lower molecular mass antigens, all of which reacted with antiserum to the $270 \mathrm{kDa}$ IgBP. Plasmid pHS137 produced minimal amounts of the same proteins. The same bands were observed with the larger pHS139, although the $5 \mathrm{~kb}$ insert was in the opposite orientation with respect to the lac $Z$ promoter from $\mathrm{pHS138.} \mathrm{This}$ indicates that expression in $E$. coli of pHS139 was from a promoter originating from $H$. somnus, but that highlevel expression in pHS138 was from the vector lac $Z$ promoter.

DNA sequence analysis of the $5 \mathrm{~kb} \mathrm{XbaI-PvuII}$ insert from $\mathrm{pHS} 139$ revealed a single $4.5 \mathrm{~kb}$ ORF, with no other ORF present in any other frame. The ORF may 
1681 ATA CAA AAA GGA AGT GCG GTA GAT GAT CTC AAT GCA CAA ACT TTA GCG ATT ACA GAA GCT 1741

TTA GCA GAT ACG TCA AAA ACA ATT CAA CGT AAT CCA AAA TTG AAA GAA GAA GTT CAA GGT 1801 * * * HpaI * A $76 \mathrm{kDa}$ * GCG ATT GAA GAA TITT TTG AAA AGT AGT CAG GGC AAA GAG TTA ACT GTA GAG ATG ATC GAA

1861 * * * $\quad$ PvuI * *

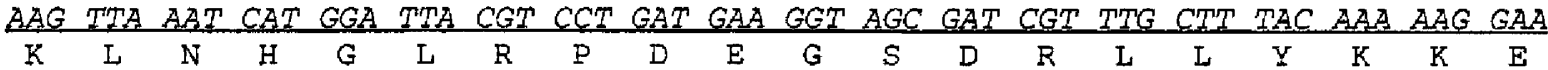
1921 TTA ACT AAA GAA AAT GCG GTA TITT TCC $\begin{array}{lllllllllllllllllllll}\mathrm{N} & \mathrm{L} & \mathrm{T} & \mathrm{K} & \mathrm{E} & \mathrm{N} & \mathrm{A} & \mathrm{V} & \mathrm{F} & \mathrm{S} & \mathrm{S} & \mathrm{P} & \mathrm{Q} & \mathrm{A} & \mathrm{S} & \mathrm{K} & \mathrm{I} & \mathrm{Q} & \mathrm{L} & \mathrm{N}\end{array}$ 1981 GAA ACA GTG GAC TTT ATT AAC CAA GCA ATC AAG CAA AAT GTG GAA CCA AGT GTT TTA GCG $\begin{array}{llllllllllllllllllll}E & \mathrm{~T} & \mathrm{~V} & \mathrm{D} & \mathrm{F} & \mathrm{I} & \mathrm{N} & \mathrm{Q} & \mathrm{A} & \mathrm{I} & \mathrm{K} & \mathrm{Q} & \mathrm{N} & \mathrm{V} & \mathrm{E} & \mathrm{P} & \mathrm{S} & \mathrm{V} & \mathrm{I} & \mathrm{A}\end{array}$ 2041 * * * * * * * GGG TTG GTT TAT CAG CGA TTA ATT GCG TAC CAT CCG TTC GCA GAA GGG AAT GGT CGA ATG $\begin{array}{lllllllllllllllllllllll}G & L & V & Y & Q & R & L & I & A & Y & H & P & F & A & E & G & N & G & R & M\end{array}$ 2101 * * * * $\quad$ * $\begin{array}{clllllllllllllllllll}A & R & V & V & V & N & K & I & L & L_{*} & D & A & G & Y & P & P & F & F & K & F\end{array}$ AGT TCT GAA TUTT GAA ACG CAG ATC ATT CCE CAA ACA AAA GCT ACG GCT AAA TCA GCA ACA

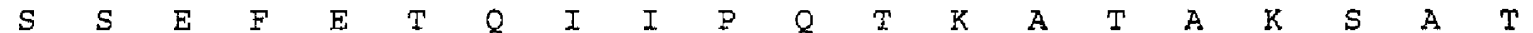

2221 * * * * * * * AGT GCG GAA GTT GTG AAA GAG TTT TTG ACT GAA TTA GGT AAA AAA TCA TCT CCG CAA GAG $\begin{array}{lllllllllllllllllllll}\mathrm{S} & \mathrm{A} & \mathrm{E} & \mathrm{V} & \mathrm{V} & \mathrm{K} & \mathrm{E} & \mathrm{F} & \mathrm{L} & \mathrm{T} & \mathrm{E} & \mathrm{L} & \mathrm{G} & \mathrm{K} & \mathrm{K} & \mathrm{S} & \mathrm{S} & \mathrm{P} & \mathrm{Q} & \mathrm{E}\end{array}$ 2281 GGA GGT GCG AAT AAT CAA AAC GGA CAA GCG ACT TCG CCT GTT ACG TTG AAG TCT AAA GAT $\begin{array}{lllllllllllllllllllll}G & G & A & N & N & Q & N & G & Q & A & T & S & P & V & T & L & K & S & K & D\end{array}$ 2341 GTT AGT GAA GTC GAA AAC ACA CAA TCC GCA GAC AGT TTG ACC ATT AAA CAG CCG GAA CAA $\begin{array}{llllllllllllllllllllllllll}V & S & E & V & E & N & T & Q & S & A & D & S & I & T & I & K & Q & P & E & Q\end{array}$ 2401 * * * * 2 *

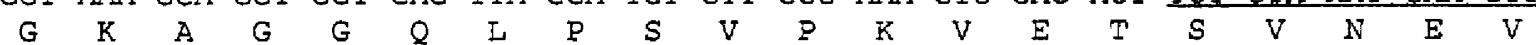
2461 GCA CCG TTG TCA TCT GTA CCA GCA GAA CTA AAA GAT GCT GCT GGA GGA AAT AAA AAA GCG $\begin{array}{llllllllllllllllllllll}A & P & L & S & S & V & P & A & E & \text { L } & \text { K } & D & A & A & G & G & N & K & K & A\end{array}$ 2521 GCA GAG AAA TCA GAG GGT GCT ACG GGT GTA GAA AAA GAA AAA ACC ACA CंTT TTC CAA CGA $\begin{array}{lllllllllllllllllllll}A & E & K & S & E & G & A & T & G & V & E & K & E & K & T & T & \text { L } & F & Q & R\end{array}$

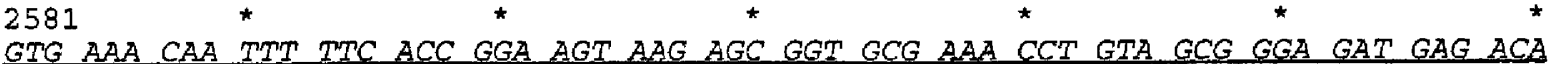
$\begin{array}{llllllllllllllllllll}V & K & Q & F & F & T & G & S & K & S & G & A & K & P & V & A & G & D & E & T\end{array}$ 2641 GCG AAT AAA GTC AAT TAT CAA GAT TTG GAA GAT AAT TTG AAC TTA AAA GGA TTA ATT TCT $\begin{array}{lllllllllllllllllllll}A & N & K & V & N & Y & Q & D & \text { L } & E & D & N & \text { L } & N & \text { L } & \text { K } & G & \text { L } & \text { I } & S\end{array}$ 


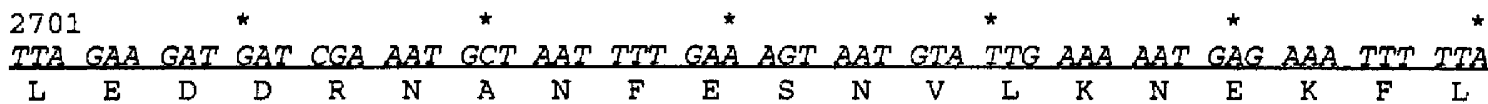

$2761 * *$ * * * * * * *

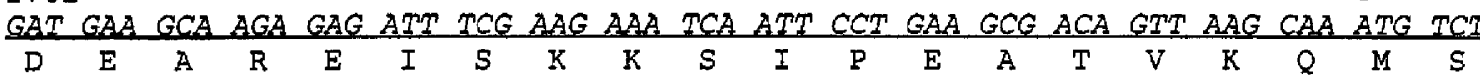

2821

\begin{tabular}{ccccccccccccccccccccc} 
CAT & $T T A$ & $C C T$ & $G A A$ & $T T P$ & $G A T$ & $G A T$ & $A T T$ & $C T C$ & $A C C$ & $G A G$ & $G G A$ & $G C T$ & $A A G$ & $A A A$ & $G T A$ & $G A A$ & $A G T$ & $C G T$ & ATT \\
\hline H & L & P & E & F & D & D & I & L & T & E & G & A & K & K & $V$ & E & S & R & I
\end{tabular}

2881 * * * * * * * * *

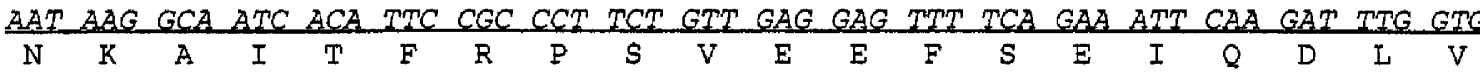

2941 AAA ACG TTA $C$ CG AAA ACA AAG GTT ATA GAG GAT CTT TCA ACA AAA ACA AAT GAA ATC ACA $\begin{array}{llllllllllllllllllll}K & T & \text { L } & \text { P } & \text { K } & \text { T } & \text { K } & \text { V } & \text { I } & \text { E } & \text { D } & \text { I } & \text { S } & \text { T } & \text { K } & \text { T } & \text { N } & \text { E } & \text { I } & \text { T }\end{array}$

3001 GAA GCT TTA GCT GCG ACA TCG AAA ACC ATT CAA CGT ACA CCG GAG TTG AAA GAA CAG TTO $\begin{array}{llllllllllllllllllll}E & A & L & A & A & T & S & K & T & I & Q & R & T & P & E & I & K & E & Q & I\end{array}$

3061 AAG ACA GCA ATA GAG GAT TTC TTA CAA AAC AGT CAA GGC AAA CCT TTG ACA GTG CAG ATG $\begin{array}{llllllllllllllllllll}\mathrm{K} & \mathrm{T} & \mathrm{A} & \mathrm{I} & \mathrm{E} & \mathrm{D} & \mathrm{F} & \mathrm{I} & \mathrm{Q} & \mathrm{N} & \mathrm{S} & \mathrm{Q} & \mathrm{G} & \mathrm{K} & \mathrm{P} & \mathrm{I} & \mathrm{T} & \mathrm{V} & \mathrm{Q} & \mathrm{M}\end{array}$

3121 * * * * * * * ATC GAG AAT CTT AAT CAC GGA TTA CGT CCG GAT GAG GGA GAA GGT CGT TTA CTT TAT AAA

3181 * * * * * * *

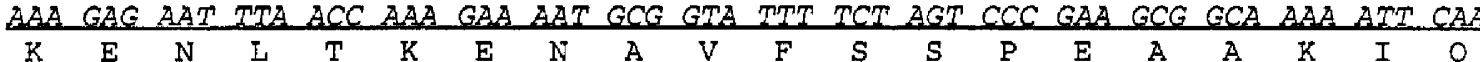

3241 * * * * * * * *

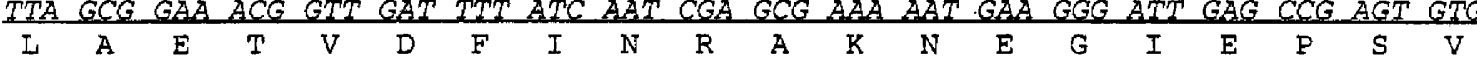
3301 * * * * * * * * * \begin{tabular}{llllllllllllllllllllll}
$G T T$ & $G G G$ & $G C A$ & $T T A$ & $G T T$ & $T A T$ & $C A G$ & $C G A$ & $T T G$ & $A T T$ & $G C T$ & $T A T$ & $C A C$ & $C C A$ & $T T T$ & $G C A$ & $G A A$ & $G G T$ & $A A T$ & $G G A$ \\
\hline $\mathrm{V}$ & $G$ & A & L & V & Y & Q & R & L & I & A & Y & H & P & F & A & E & G & N & $G$
\end{tabular} 3361 CGT ATG GCG AGA GTC ATA GTA AAT AAA ATT TTA CTT GAT GCA GGT TAT CCG GCA TTT ACC $\begin{array}{llllllllllllllllllll}R & M & A & R & V & I & V & N & K & I & \text { L } & \text { I } & \text { D } & \text { A } & \text { G } & \text { Y } & \text { P } & \text { A } & \text { F } & \text { T }\end{array}$ 3421 TAT AGT GAT GAG TTT GAA CCG CAG ATT ATT CCT CAA ACG AAA GCA TCA ACT AAA TCC $\begin{array}{llllllllllllllllllll}K & F & S & D & E & F & E & P & Q & I & I & P & Q & T & K & A & S & T & K & S\end{array}$ 3481 GCA ACG AGC AGT GAA GTG GTA GTT GAG TTT TTA AAA GAG TTG GCA AAA AAA GGA AGC AAG $\begin{array}{llllllllllllllllllll}A & \text { T } & S & S & E & V & V & V & E & F & \text { L } & \text { K } & \text { E } & \text { L } & \text { A } & K & K & G & S & K\end{array}$ 3541 GAA GAT AAC GAG CAG AAT TTA GAA AAA ACT GAC CGC ACT TCT ACG GAC TTG ACA GAA AGT $\begin{array}{llllllllllllllllllll}E & D & N & E & Q & N & I & E & K & T & D & R & T & S & T & D & L & T & E & S\end{array}$ 3601 * * * * * * * * *

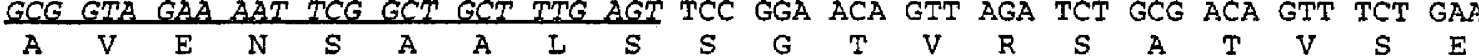
3661 ACA GTT ACT GAA ACG GAA CAG GCA AAA GCG AAA CCA GTT AGT GAT TTG GTG AGC AGT AAA

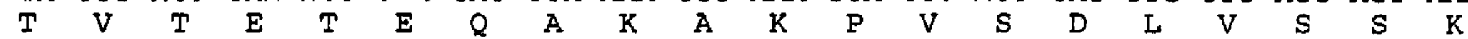




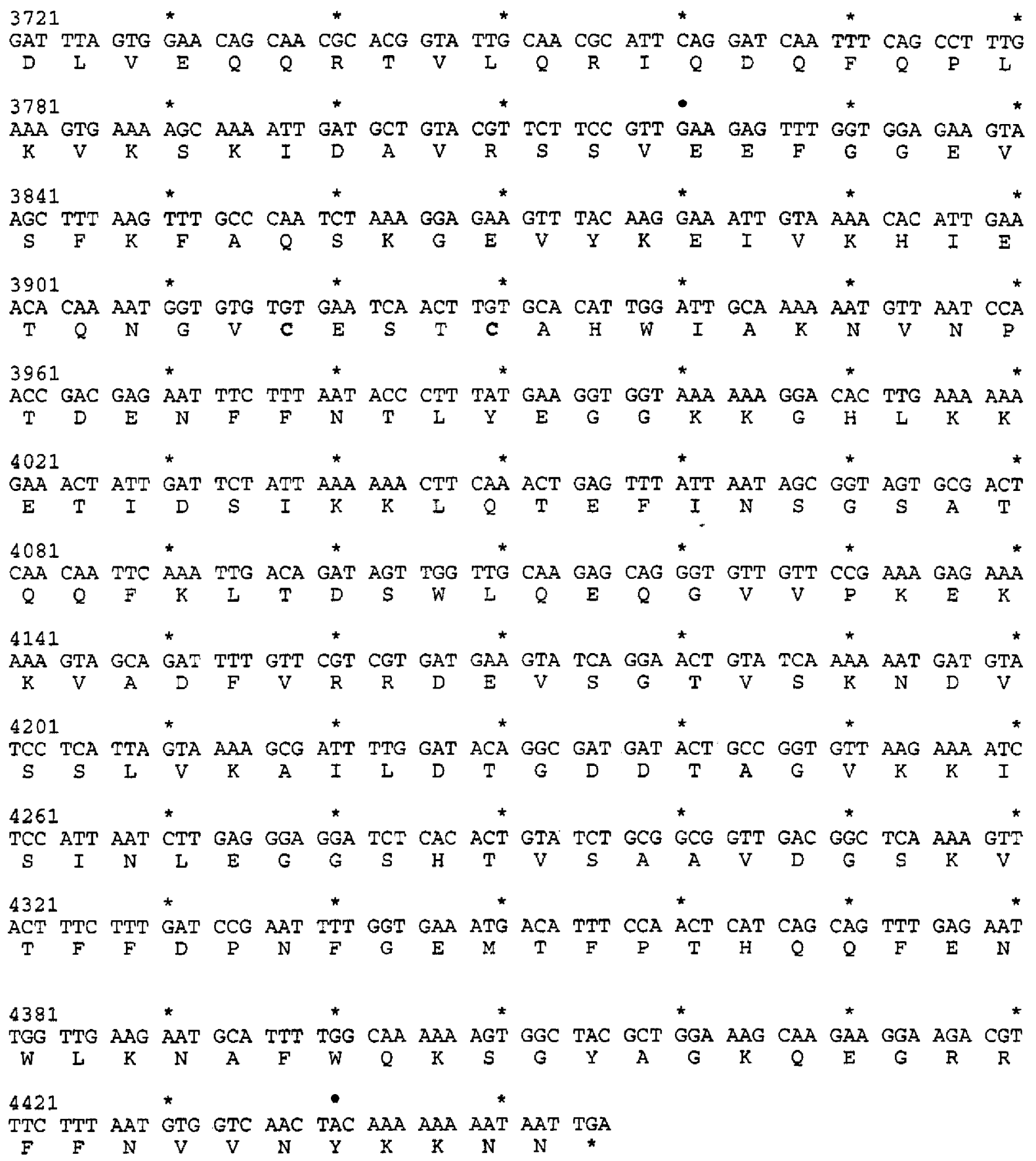

Fig. 1. p76 gene sequence and upstream DNA region. The two direct repeats (DRs) are italicized and underlined. Since the p76 gene starts translation in the middle of DR1, only that portion of DR1 that codes for p76 and some of the upstream sequence is shown. Arrows indicate inverted repeats flanking DR2. Sequence locations are in base pairs, originating from the XhaI site of pHS139. HpaI and $P v u$ I sites are located in the plasmid insert (Figs 2 and 4). Possible ATG start sites, also indicated in Fig. 4, are labelled A, B and C.

extend further upstream from the sequence reported in this paper, since no stop codon was encountered. The GC content of the entire $4.5 \mathrm{~kb}$ ORF is $39 \cdot 3 \%$, which is consistent with the published sequence of the $H$. somnus ribosomal RNA gene and flanking two ORFs (38.7\%) (Theisen \& Potter, 1992), the $40 \mathrm{kDa} H$. somnus lipoprotein (36.2\%) (Theisen et al., 1992), and the previously determined value $(37 \cdot 3 \% \pm 0 \cdot 2)$ for total $H$. somnus DNA (Bailie et al., 1973). The sequence for the p76 coding region is presented in Fig. 1. The derived amino acid sequence of $\mathrm{p} 76$ was analysed for hydrophilicity using the algorithm of Kyte \& Doolittle (1982) 


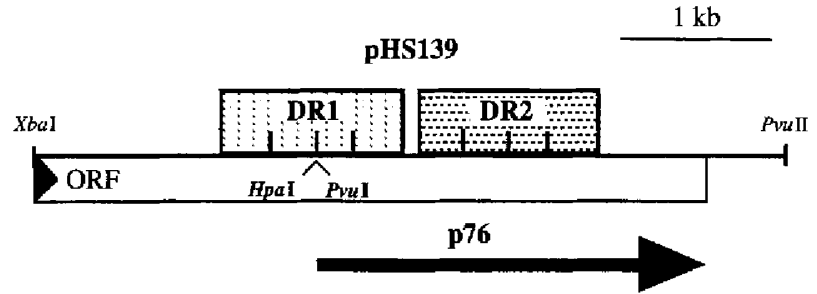

Fig. 2. The $4.5 \mathrm{~kb}$ ORF of pHS139, showing the two DRs and the $p 76$ gene (arrow). The translational start site for the 76 gene lies between the $H p a \mathrm{I}$ and $P v u \mathrm{I}$ restriction sites (see Fig. 4). The three repeated methionines within each $D R$ are indicated by vertical bars above the horizontal line representing the sequence.

with a window size of seven residues (data not shown). The peptide was predicted to be highly hydrophilic, with no long hydrophobic regions characteristic of a membrane-spanning protein, and did not contain an obvious signal sequence (Von Heijne, 1983). Our earlier studies showed the H. somnus $76 \mathrm{kDa}$ surface protein to be shed in the soluble fraction of culture supernatant (S. A. Kania, M. Yarnall \& L. B. Corbeil, unpublished data). These observations suggest that $\mathrm{p} 76$ may be a peripheral membrane protein or a surface protein rather than an integral membrane protein.

A striking feature of the large ORF is the presence of two large, approximately $1.2 \mathrm{~kb}$ direct repeats (DRs Fig. 2), one of which (DR2) is flanked by an imperfect inverted repeat of $11 \mathrm{bp}$, with only one mismatch (Fig. 1). Although the start codon of the p76 gene is in the middle of DR 1 (see evidence below), the entire DR1 was translated in Fig. 3 in order to show the alignment of DR1 with DR2. The most homologous portion of the DRs is the centre, while the ends of the DRs tend to be more divergent (Fig. 3). Also, the two DR sequences are much more homologous at the protein level (64\% identity over 404 amino acids), than at the DNA level ( $31 \%$ identity).

Because of the inverted repeats flanking DR2 and the size similarity to other insertion sequences, it was of interest to explore the possibility that the DRs represent a foreign inserted sequence. Therefore, codon usage of the translated region of DR2 was compared (data not shown) to that of the C-terminus of the p76 ORF as well

DR 1 SVALGTPKSAV-AESNRNNNGNQKLQSEGAEGVSPKTKSEDKSWFARVKDFFFAKSNKSQA

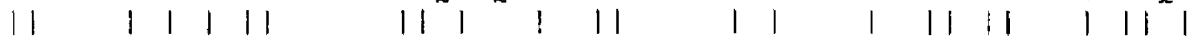

DR 2 SVNEVA.PLSSVPAELKDAAGGNKKAA-EKSEGATGVEK-EKTTLFORVKOFFTG-S-KSGA

DR 1 KEAKSEQETVSKPNYDSLEDDLNLKNLLALEDKRGSSFEENVLKNPEFLAEAREIAKKYIP

DR2 KPVAG-DETANKVNYODLEDNLNLKGLISLEDDRNANEESNVLKNEKELDEAREISKKSIP

DR 1 EATIKQMGNSPEFDEILTEGAKKVEKRINDALTFKPSVDEFNEIQGLVKNIQKGSAVDDLN

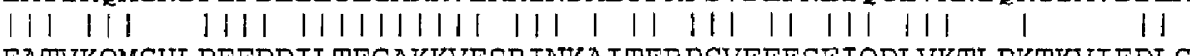

DR 2 EATVKOMSHLPEFDDILTEGAKKVESRINKAITFRPSVEEF SEIODLVKTL FKTKVIEDISS

DR 1 AQTLAITEALADTSKTIQRNPKLKEEVQGAIEEFIKSSQGKELTVEMIEKLNHGLRPDEGS | |||||||||||||||| ||| ||||||||||||||||||||||

DR 2 TKTNEITEALAATSKTIORTPELKEOLKTA IEDFLONSOGKPLTVOMIENLNHGLRPDEGE

DR I DRLLYKKENLTKENAVESSPOASKIOLNETVDFINOAIKONVEPSVLAGLVYORLIAYHPF

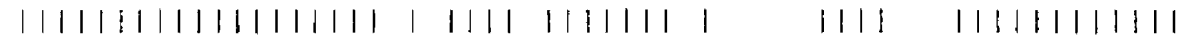

DR2 GRLLYKKENLTKENAVFSSPEAAKIOLAETVDF INRAKNEGIEPSVVGALVYORLIAYHPF

DR 1 AEGNGRMARVVVNKILLDAGYPRETKE SSEFETOI IPOTKATAKSAT SAEVVREELTELGK

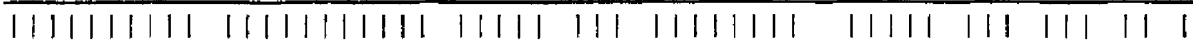

DR 2 AEGNGRMARVIVNKILLDAGYRAFTKF SDEFEPOIIPOTKASTKSATSSEVVVEFLKELAK

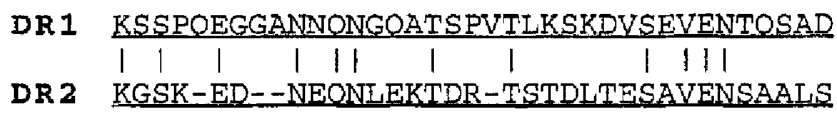

Fig. 3. Alignment of the DNA and translated protein sequences of the two DRs. The portion of DR1 upstream of the translational start site for $\mathrm{p} 76$ is indicated in italics. The coding sequence for $\mathrm{p} 76$ is underlined. Vertical lines represent identities at the protein level. 


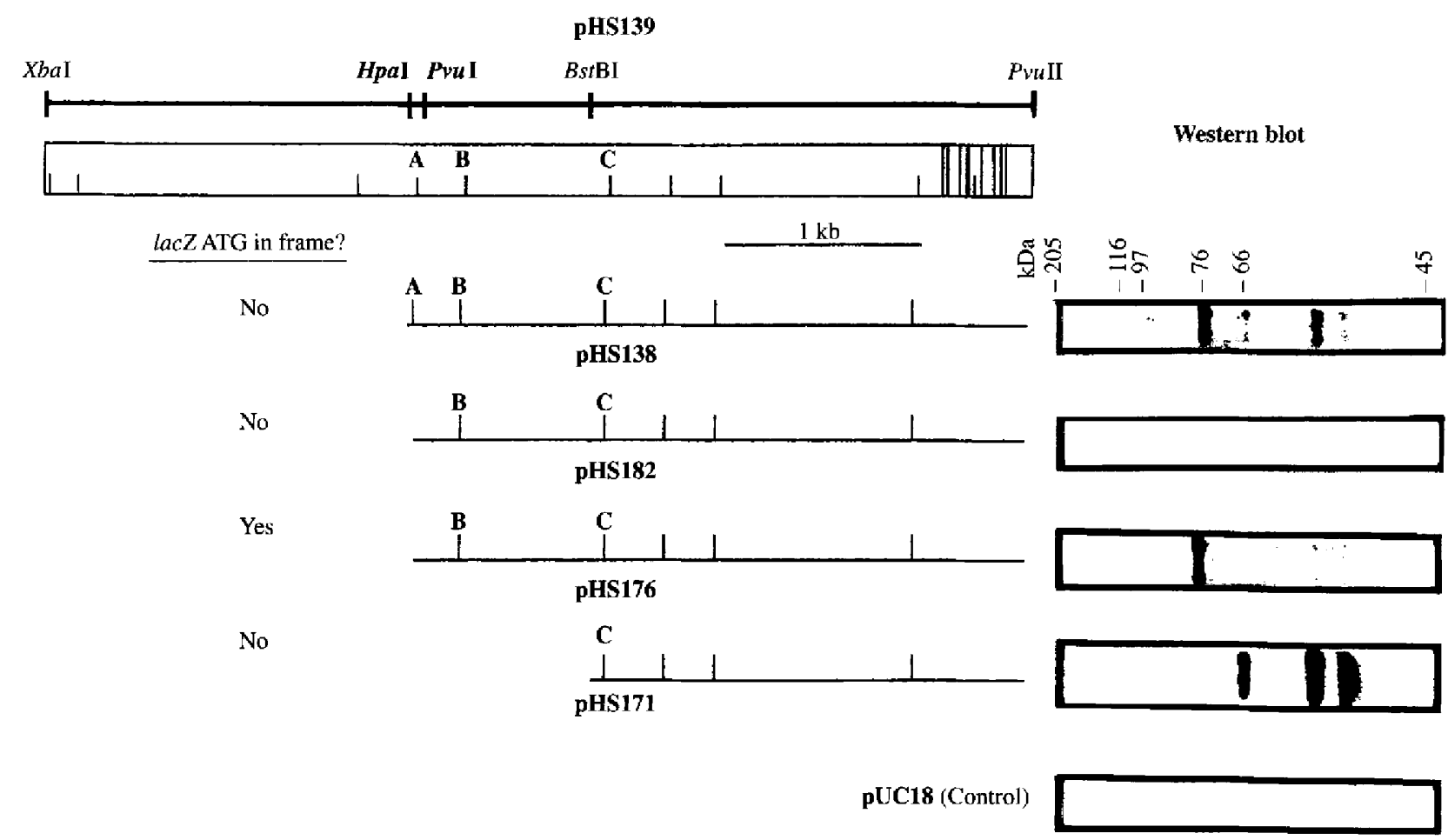

Fig. 4. Left. Inserts from subclones of pHS139, in the vectors pUC18 or 19, used in deletion analysis. The restriction map of the insert from pHS139 is indicated at the 1op. The ORF, with stop codons and ATG codons as in Fig. 1, is shown below. The ATG codons discussed in the text are indicated A, B and C. Possible translational fusions with the start ATG codon of lac Z are indicated. Right. Western blot of deletion derivatives reacted with $\mathrm{P} 3$ convalescent-phase serum. Molecular masses are indicated in kDa.

as four other published $H$. somnus ORFs (Theisen \& Potter, 1992; Theisen et al., 1992). For five amino acids [leucine (UUG), valine, threonine, alanine and glycine] guanine was preferred more as the third base of the codon for DR2 as compared to the other four $H$. somnus ORFs. There was a concomitant decrease in the use of adenine as the third base for these amino acids, with the exception of glycine. The most notable differences between DR2 and the C-terminus of the p76 ORF were with the codon usage of leucine, isoleucine, proline and tyrosine. For the rest of the 20 main amino acids, there was no significant difference between DR2 and these other $H$. somnus sequences. Since DR2 varied in its codon usage from other $H$. somnus sequences, DR2 codon usage was further compared to that of the closely related bovine pathogen Pasteurella haemolytica (Lo, 1992), as well as to E. coli (Sharp et al., 1988), host of many other insertion sequences. In both cases, the codon usage differed significantly from DR2 (data not shown); thus it is improbable that the DRs originated from either of these other organisms. Nevertheless, since the sequence of DR 1 differs substantially from DR2, it appears likely that if insertion and duplication events occurred, they happened long ago.

There have been numerous instances of insertion elements affecting the expression of genes involved in virulence, including IS 1 inserts in the virF gene (an invasion-positive regulator) of Shigella flexneri 2a (Mills et al., 1992), a mosaic of multiple insertion-sequence-like elements upstream of the Pseudomonas aeruginosa exotoxin A gene (Pritchard \& Vasil, 1990), and three tandem insertion-sequence-like elements upstream of variable antigen genes in Borrelia hermsii (Barbour et al., 1991). Thus precedence exists for these insertionsequence-like DRs of $H$. somnus to play a role in the expression of the $\mathrm{p} 76$ gene.

No ATG codon in the sequence was an obvious translational start site, providing an appropriate length of ORF to give a theoretical $76 \mathrm{kDa}$ protein. Thus, an attempt was made to find the start site for this gene by deletion analysis. Subclones of pHS138 were constructed (Fig. 4) and their cell lysates analysed for expression by Western blotting. The blots were incubated with P3 bovine convalescent phase serum, which previously was shown to react with the 270,120 and $76 \mathrm{kDa}$ surface proteins of H. somnus (Cole et al., 1992; Corbeil et al., 1988). The Western blots, also shown in Fig. 4, indicate that some inserts encoded proteins that react with $\mathrm{P} 3$ convalescent serum. The control cell lysate (E. coli $\mathrm{DH} 5 \alpha$ with pUC18 alone) did not react with the antiserum 
under these conditions. In addition, a subclone (pHS145, with a $1 \mathrm{~kb}$ insert containing $0.5 \mathrm{~kb}$ of the $3^{\prime}$ end of the ORF) encodes enough of the sequence to express a $23 \mathrm{kDa}$ protein that reacts with $\mathrm{P} 3$ bovine convalescent antisera (data not shown). This suggests that at least one epitope on p76 that reacts with P3 antibody is within 167 amino acids from the C-terminus of the protein.

DR1 overlaps the putative translational initiation region of $\mathrm{p} 76$, since pHS138 expresses $\mathrm{p} 76$ and DR 1 spans the HpaI site in pHS139 that was used to derive pHS138 (Figs 2 and 4). Also, each DR contains three ATG codons, which are repeated faithfully. All three of these ATG codons (labelled A, B and C in Figs 1 and 4) were candidates for start codons for synthesis of $\mathrm{p} 76$, as sufficient sequence remains in the ORF to encode a protein of that molecular mass. The starting plasmid, pHS138, contains all three of the ATG codons, and is not in frame with the $l a c Z$ protein to make a translational fusion. It expresses p 76, plus some lower molecular mass antigens (weaker bands on the Western blot). Subclone pHS182 is missing codon A, but has B and C, and also is not in frame for a fusion with LacZ. However, this subclone does not express any antigens detected by the P3 antiserum. pHS176 contains the same insert as pHS182, but is in the proper frame with the lacZ start site to make a translational fusion protein. This clone expresses p76, plus some of the lower molecular mass antigens appearing as weaker bands on the Western blot. The insert which contains only start codon $\mathrm{C}$, in pHS171, is not in frame to make a lac $Z$ translational fusion protein, but does encode some of the same antigens below $76 \mathrm{kDa}$ as pHS138. Plasmids pHS182, 176 and 171 were all deletion derivatives of pHS138, and thus all contained the lac $Z$ promoter in the proper orientation to the $H$. somnus ORF. Since pHS138 expressed p76, and pHS182 does not, the start codon for p76 must lie between the HpaI site (contained in pHS138, but not 182 ) and the $P v u \mathrm{I}$ site (present in both plasmids). Since no other known start codons (TTG or GTG) are present within these two restriction sites, the start codon for $\mathrm{p} 76$ must be the ATG codon A. A possible ribosome binding site (AAAGAG) located $12 \mathrm{bp}$ from the translational start may be functional in pHS139. This site occurs just upstream of the $H p a \mathrm{I}$ restriction site and would thus be deleted in pHS138, explaining the orientation-specific effect of the insert in this clone.

Since translation from codon A could theoretically produce a protein of $87 \mathrm{kDa}$, the protein must either be processed to form $\mathrm{p} 76$ or the protein runs anomalously on SDS-PAGE gels. An example of the former situation was found for the $120 \mathrm{kDa}$ Rickettsia rickettsii OMP (Gilmore et al., 1989, 1991), which contains enough DNA in the ORF to encode a deduced $168 \mathrm{kDa}$ protein. Post-translational processing of the C-terminus appar- ently gives rise to the $120 \mathrm{kDa}$ product, since a $32 \mathrm{kDa}$ peptide with the same sequence as the $3^{\prime}$ end of the large ORF was found (Gilmore et al., 1991). Interestingly, the $120 \mathrm{kDa}$ ORF of $R$. rickettsii is also similar to H. somnus p76 since both contain only two cysteines (Gilmore $\mathrm{et} \mathrm{al}$., 1989), providing minimal intramolecular disulphide bonding. The presence of only two cysteines in the $H$. somnus ORF explains the fact that no difference was observed (Cole et al., 1992) in protein migration in SDSPAGE gels run with and without urea, or with and without $\beta$-mercaptoethanol in the loading buffer. Those experiments, along with inclusion of protease inhibitors in the samples (Cole et al., 1992), suggested that the multitude of bands observed on SDS-PAGE gels for recombinants containing the $76 \mathrm{kDa}$ ORF was not due to artifacts such as monomer polymerization or in vitro proteolytic degradation of the $H$. sommus proteins.

The expression of lower molecular mass antigens at 66 , 52 and $55 \mathrm{kDa}$ by pHS171 which has codon C but not $\mathrm{A}$ or $\mathrm{B}$, could be due to use of additional start codons. Codon $\mathrm{C}$ as a start site could produce a protein of theoretical molecular mass $52 \mathrm{kDa}$. The other two antigens may migrate anomalously on SDS-PAGE gels, or be modification $(66 \mathrm{kDa})$ or degradation $(50 \mathrm{kDa})$ products of the $52 \mathrm{kDa}$ protein. These proteins were also expressed by pHS138. Expression from this alternative start site (codon $\mathrm{C}$ ) within the $76 \mathrm{kDa}$ ORF of lower molecular mass proteins could explain the multiple banding patterns on Western blots observed previously (Cole et al., 1992). The use of more than one translational initiation site within an ORF has been described for numerous genes, including the $\mathrm{McrB}$ restriction system of E. coli (Ross et al., 1989), as well as several phage (Dunn \& Studier, 1983; Eisenberg \& Finer, 1980; Fulford \& Model, 1988) and transposon (Isberg et al., 1982; Johnson \& Reznikoff, 1984) genes. Expression of a Mycoplasma hyorhinis gene in E. coli resulted in the translation of related polypeptides of 110, 100,65 and $55 \mathrm{kDa}$ from an ORF of just over $3 \mathrm{~kb}$ (Notarnicola et al., 1990). Tryptic peptide analysis revealed that these proteins all shared a common C-terminus, suggesting that all proteins were translated from a single message. A similar mechanism may occur for $H$. somnus $\mathrm{p} 76$ and lower molecular mass proteins.

In conclusion, the DRs and p76 DNA coding sequence lie within a $13.4 \mathrm{~kb}$ segment that is present in two virulent serum resistant strains, and absent in all four of the serum sensitive strains tested (Cole et al., 1992). The $13.4 \mathrm{~kb}$ segment contains an ORF of at least $4.5 \mathrm{~kb}$, with multiple start sites functional in $E$. coli and two $1.2 \mathrm{~kb}$ DRs. The coding sequence for p76 starts in DR 1 and continues beyond DR2, which has flanking inverted repeats similar to insertion elements. The duplicated DRs are thus essential to the expression of a hydrophilic 
$76 \mathrm{kDa}$ surface protein which is associated with serum resistance and virulence.

This work was supported, in part, by grant $89-37265-4648$ from the United States Department of Agriculture.

\section{References}

Bailie, W. E., Coles, E. H. \& Weide, K. D. (1973). Deoxyribonucleic acid characterization of a microorganism isolated from infectious thromboembolic meningoencephalomyelitis of cattle. International Journal of Systematic Bacteriology 23, 231-237.

Barbour, A. G., Carter, C. J., Burman, N., Freitag, C. S., Garon, C.F. \& BergSTRom, S. (1991). Tandem insertion sequence-like elements define the expression site for variable antigen genes of Borrelia hermsii. Infection and Immunity 59, 390-397.

Cole, S. P., Guiney, D. G. \& Corbeit, L. B. (1992). Two linked genes for outer membrane proteins are absent in four non-disease strains of Haemophilus somnus. Molecular Microbiology 6, 1895-1902.

Corbeil, L. B., Blau, K., Prieur, D. J. \& Ward, A. C. S. (1985). Serum susceptibility of Haemophilus somnus from bovine clinical cases and carriers. Journal of Clinical Microbiology 22, 192-198.

Corbeil, L. B., Chikami, G., Yarnall, M., Smith, J. \& Guiney, D. G. (1988). Cloning and expression of genes encoding Haemophilus somnus antigens. Infection and Immunity 56, 2736-2742.

DUNN, J. J. \& STUdier, F. W. (1983). Complete nucleotide sequence of bacteriophage T7 DNA and the locations of T7 genetic elements. Journal of Molecular Biology 166, 477-535.

EISENBERG, S. \& FINER, M. (1980). Cleavage and circularization of single-stranded DNA: a novel enzymatic activity of $\phi \times 174 \mathrm{~A}^{*}$ protein. Nucleic Acids Research 22, 5305-5315.

FULFord, W. \& Model, P. (1988). Regulation of bacteriophage fl DNA replication. I. New functions for genes $I I$ and $X$. Journal of Molecular Biology 203, 49-62.

Gilmore, R. D., JR, Joste, N. \& MCDonald, G. A. (1989). Cloning, expression and sequence analysis of the gene encoding the $120 \mathrm{kDa}$ surface-exposed protein of Rickettsia rickettsii. Molecular Microbiology 3, 1579-1586.

Gilmore, R. D., JR, Cieplak, W., JR, Policastro, P. F. \& Hackstadt, T. (1991). The 120 kilodalton outer membrane protein (rOmpB) of Rickettsia rickettsii is encoded by an unusually long open reading frame: evidence for protein processing from a large precursor. Molecular Microbiology 5, 2361-2370.

Gogolewski, R. P., Kania, S. A., Inzana, T. J., Widders, P. R., Liggitt, H. D. \& Corbeil, L. B. (1987). Protective ability and specificity of convalescent serum from calves with Haemophilus somnus pneumonia. Infection and Immunity 55, 1403-1411.

Groom, S. C., Little, P. B. \& Rosendal, S. (1988). Virulence differences among three strains of Haemophilus somnus following intratracheal inoculation of calves. Canadian Journal of Veterinary Research 52, 349-354.

HARRIS, F. W. \& JANZEN, E. D. (1989). The Haemophilus sommus disease complex (Hemophilosis): a review. Canadian Veterinary Journal 30, 816-820.

Holmes, D. S. \& Quigley, M. (1981). A rapid boiling method for the preparation of bacterial plasmids. Analytical Biochemistry 114, 193-197.

HUMPHREY, J. D. (1982). Haemophilus somnus: colonization of the bovine reproductive tract. [As quoted in Groom et al. (1988) and Humphrey \& Stephens (1983).] PhD thesis, University of Guelph, Ont., Canada.

Humphrey, J. D. \& STEPHENS, L. R. (1983). Haemophilus somnus: a review. Veterinary Bulletin 53, 987-1004.
InZANA, T. J. \& CoRBEIL, L. B. (1987). Further characterization of the growth requirements of Haemophilus somnus: development of a defined medium. American Journal of Veterinary Research 48 , $366-369$

INZANA, T. J. \& TODD, J. T. (1992). Immune response of cattle to Haemophilus somnus lipid A-protein conjugate vaccine and efficacy in a mouse abortion model. American Journal of Veterinary Research $53,175-179$.

IsBeRG, R. R., LAAZAAR, A. L. \& Syvanen, M. (1982). Regulation of $\mathrm{Tn} 5$ by the right-repeat proteins: control at the level of the transposition reaction. Cell 30, 883-892.

Johnson, R. C. \& ReZnikoFf, W. S. (1984). Role of the IS50R proteins in the promotion and control of Tn5 transposition. Journal of Molecular Biology 177, 645-661.

Kwiecien, J. M. \& LiTTLE, P. B. (1991). Haemophilus somnus and reproductive disease in the cow: a review. Canadian Veterinary Journal 32, 595-601.

KYTE, J. \& DoolitTle, R. F. (1982). A simple method for displaying the hydropathic character of a protein. Journal of Molecular Biology $157,105-132$.

Lo, R. Y. (1992). An analysis of the codon usage of Pasteurella haemolytica A1. FEMS Microbiology Letters 79, 125-131.

Mills, J. A., Venkatesan, M. M., Baron, L. S. \& Buysse, J. M. (1992). Spontaneous insertion of an IS 1 -like element into the virF gene is responsible for avirulence in opaque colonial variants of Shigella flexneri 2a. Infection and Immunity 60, 175-182.

Notarnicola, S. M., MCINTosh, M. A. \& WISE, K. S. (1990). Multiple translational products from a Mycoplasma hyorhinis gene expressed in Escherichia coli. Journal of Bacteriology 172, 2986-2995.

Pritchard, A. E. \& Vasil, M. L. (1990). Possible insertion sequences in a mosaic genome organization upstream of the exotoxin $A$ gene in Pseudomonas aeruginosa. Journal of Bacteriology 172, 2020-2028.

Ross, T. K., AchBerger, E. C. \& Braymer, H. D. (1989). Nucleotide sequence of the McrB region of Escherichia coli $\mathrm{K}-12$ and evidence for two independent translational initiation sites at the $\operatorname{mcr} B$ locus. Journal of Bacteriology 171, 1974-1981.

SambroOK, J., Fritsch, E. F. \& Maniatis, T. (1989). Molecular Cloning: A Laboratory Manual. Cold Spring Harbor, NY: Cold Spring Harbor Laboratory.

Sharp, P. M., Cowe, E., Higgins, D. G., Shields, D. C., Wolfe, K. H. \& WRIGHT, F. (1988). Codon usage patterns in Escherichia coli, Bacillus subtilis, Saccharomyces cereviriae, Schizosaccharomyces pombe, Drosophila melanogaster and Homo sapiens; a review of the considerable within-species diversity. Nucleic Acids Research 16, 8207-8211.

Theisen, M. \& PotTer, A. A. (1992). Cloning, sequencing, expression, and functional studies of a 15000-molecular-weight Haemophilus somnus antigen similar to Escherichia coli ribosomal protein S9. Journal of Bacteriology 174, 17-23.

Theisen, M., Rioux, C. R. \& Potter, A. A. (1992). Molecular cloning, nucleotide sequence, and characterization of a 40000-molecularweight lipoprotein of Haemophilus somnus. Infection and Immunity 60, 826-831.

VON HeIJNE, G. (1983). Patterns of amino acids near signal-sequence cleavage sites. European Journal of Biochemistry 133, 17-21.

Widders, P. R., Paisley, L. G., Gogolewski, R. P., EvermanN, J. F., SMITH, J. W. \& CoRBeIL, L. B. (1986). Experimental abortion and the systemic immune response in cattle to Haemophilus somnus. Infection and Immunity 54, 555-560.

Widders, P. R., Dorrance, L. A., Yarnall, M. \& Corbeil, L. B. (1989). Immunoglobulin-binding activity among pathogenic and carrier isolates of Haemophilus somnus. Infection and Immunity 57, 639-642.

YaRnali, M., Gogolewski, R. P. \& CoRbeil, L. B. (1988 a). Characterization of two Haemophilus somnus Fc receptors. Journal of General Microbiology 134, 1993-1999.

YARNALL, M., WidDers, P. R. \& CoRbeIL, L. B. (1988b). Isolation and characterization of Fc receptors from Haemophilus somnus. Scandinavian Journal of Immunology 28, 129-137. 